\title{
RNA concentration in zooplankton: seasonal variation in boreal species
}

\author{
Ulf Båmstedt
}

Tjärnö Marine Biological Laboratory, P.O. Box 2781, S-452 00 Strömstad, Sweden

\begin{abstract}
Variation in RNA concentration of 18 species of macrozooplankton from the Swedish west coast has been followed over 8 mo. There was a general trend of increasing RNA concentration from winter towards summer with maximum values usually occurring from March to June. The main seasonal variation in RNA concentration is suggested to reflect the seasonal variation in food supply and peaks to correspond to periods of high breeding intensity in species with discrete reproduction.
\end{abstract}

\section{INTRODUCTION}

A positive relationship between growth rate and RNA concentration has been found for a wide variety of organisms (e.g. bacteria: Neidhardt and Magasanic, 1960; ciliates: Leick, 1967; higher invertebrates: Sutcliffe, 1965, 1970; fish: Bulow, 1970; mammals: Munro and Gray, 1969). The ratio between the contents of RNA and DNA has been adopted sucessfully as a growth index of fish populations in both undisturbed (Haines, 1980) and polluted environments (Kearns and Atchison, 1979). Sutcliffe $(1965,1970)$ suggested that RNA measurements could be used to estimate secondary production of whole communities (mixed samples), but this was later questioned by some investigators (e.g. Dagg and Littlepage, 1972; Baudouin and Scoppa, 1975). Båmstedt and Skjoldal (1980) showed that size-dependent growth rate was positively correlated with the RNA concentration of macrozooplankton species from a boreal community. In 2 earlier studies (Båmstedt and Skjoldal, 1976; Skjoldal and Båmstedt, 1976) they found the highest RNA concentration of 2 planktonic crustaceans in spring.

During maturation of an organism, organic matter is incorporated in its gonads; this implies that body tissue is synthesized. A great majority of zooplankton species from northern latitudes have distinct reproduction periods and their breeding and growth cycles are therefore usually correlated. Since growth is the result of a positive balance between energy storage and energy utilization, food supply and feeding are determining factors for growth. Food supply in the sea varies seasonally in boreal areas, with suitable conditions for fast growth and maturation from spring to autumn. The role of RNA as a necessary precursor to protein synthesis therefore suggests a seasonal variation in RNA mainly governed by the seasonal abundance of food and associated with the growth and breeding cycles.

\section{MATERIAL AND METHODS}

Oblique hauls from about $200 \mathrm{~m}$ depth with a $1-\mathrm{m}$ diameter conical net, $0.4 \mathrm{~mm}$ mesh aperture, occasionally accompanied by a Beyer's low-speed midwater trawl, $1.0 \mathrm{~mm}$ mesh aperture, were taken every month between February and September 1976 in Kosterfjorden, western Sweden $\left(58^{\circ} 52^{\prime} \mathrm{N}, 11^{\circ} 06^{\prime} \mathrm{E}\right)$. The living zooplankton were kept in darkness in containers with seawater at 5 to $7^{\circ} \mathrm{C}$ and sorted to species in the laboratory within $5 \mathrm{~h}$ of capture. The sorted material was preserved in $70 \%$ ethanol and stored refrigerated for up to 3 mo prior to analyses. The average number of individuals comprising the samples varied between 1 (Boreomysis arctica) and 41 (Metridia longa). The analytical procedures were performed at 0 to $4{ }^{\circ} \mathrm{C}$. Samples were homogenized in $0.2 \mathrm{M}$ perchloric acid; extraction of RNA and its separation from DNA followed the method of Schmidt and Tannhauser (1945), as modified by Munro and Fleck (1966). RNA was measured by using the orcinol reaction as described by Schneider (1957), and the measured absorbance at $660 \mathrm{~nm}$ was translated to units of RNA by means of 
standard curve based on yeast RNA. The wet weight of each sample was determined with a micro balance before homogenization, after draining the material briefly on a soft paper towel. The RNA content per unit dry weight was obtained by using separately determined conversion factors between ethanol-preserved wet weight and fresh dry weight $\left(60^{\circ} \mathrm{C}, 48 \mathrm{~h}\right)$. Organic weight was determined as the weight loss upon incineration of the dried material at $500{ }^{\circ} \mathrm{C}$ for $24 \mathrm{~h}$.

\section{RESULTS}

\section{Methodological tests}

Preservation of the material in $70 \%$ ethanol caused 2 characters to change. Firstly, there was a decrease in wet weight of 60 to $75 \%$ for gelatinous species and of 0 to $20 \%$ for crustacean species during the first $2 \mathrm{~d}$, with only a slight further loss during prolonged storage for up to $3 \mathrm{mo}$. Secondly, preservation caused an increase in the organic weight/dry weight ratio of gelatinous species, indicating a preferential loss of inorganic matter. Since these changes mainly occurred during the first $2 \mathrm{~d}$ of preservation, unbiased results on the RNA concentration of different species were obtained by using a preservation time of at least $5 \mathrm{~d}$ and applying a specific conversion factor between ethanol-preserved wet weight and fresh dry weight for each species.

\section{RNA concentration in relation to size}

The multispecific relationship between individual dry weight and RNA concentration as given by using all the data from the 8 sample occasions (Fig. 1) is influenced by seasonal as well as interspecific variability; this may explain the great spread of the data around the regression line. Nevertheless, the correla- tion between individual dry weight and RNA concentration was significant (t-test, $p<0.001$ ) and the slope of the regression line describing the relationship was -0.33 . This is identical to the value found by Båmstedt and Skjoldal (1980) and may thus be a sign of a general relationship within zooplankton communities.

It is more difficult to evaluate the intraspecific relationship between individual dry weight and RNA concentration in the present material, since at each sample occasion the range in weight was narrow and the number of samples small. For the 7 species best suited for such an evaluation according to the weight range and number of samples the common regression coefficient was calculated and found to be -0.38 .

\section{Seasonal variation in RNA concentration}

The seasonal variations in the RNA concentration of 12 species are shown in Figs. 2 to 4 , as are the average dry weights of the specimens constituting the samples. Varying dry weight of the individuals sampled over the investigation period may influence the results considerably, since smaller individuals usually have more RNA per unit weight than the larger ones. Theoretically, this effect can be eliminated by using an equation describing the relationship between individual dry weight and RNA concentration to calculate the RNA concentration for individuals of 'standard weight'. The equation used was of the form (see Båmstedt and Skjoldal, 1980):

$$
(\mathrm{RNA})_{\mathrm{s}}=\mathrm{a} \mathrm{W}_{\mathrm{s}}^{-0.38}
$$

where -0.38 corresponds to the regression coefficient given above for the intraspecific relationship between individual dry weight and RNA concentration and $\mathrm{W}_{\mathrm{s}}$ denotes the standard dry weight. $\mathrm{W}_{\mathrm{s}}$ for each species was taken as the value most frequently occurring. The regression constant (a) was calculated as:

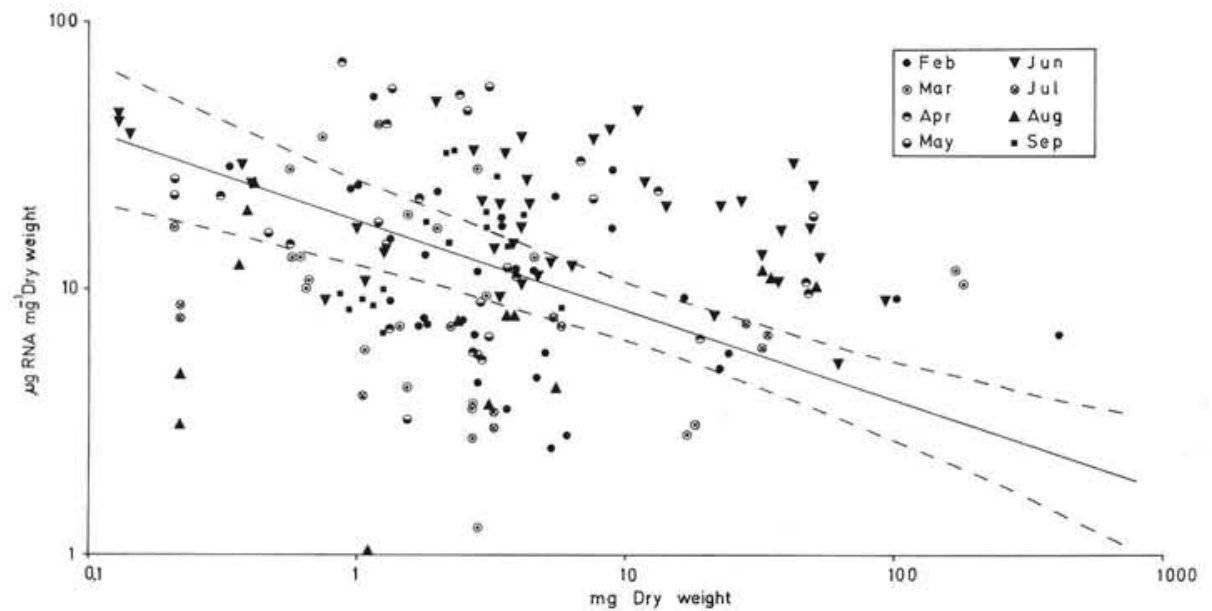

Fig. 1. Multispecific relationship between individual dry weight and RNA concentration of macrozooplankton sampled in Kosterfjorden at 8 occasions between February and September 1976. Regression equation: (RNA) = 17.722 (dry weight) ${ }^{-0.334} \cdot \mathrm{r}^{2}=$ 0.178 . The $95 \%$ confidence belt for the regression line is also shown 

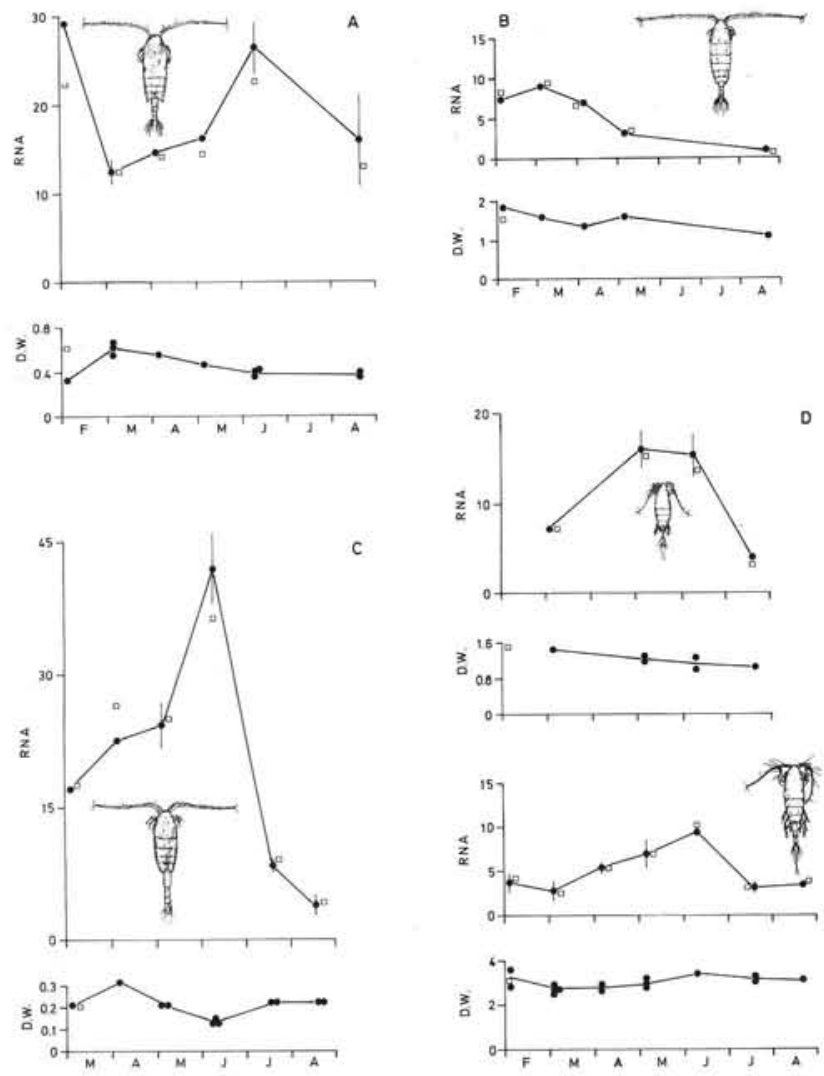

Fig. 2. Seasonal variation in RNA concentration $\left(\mu \mathrm{g} \mathrm{mg}^{-1}\right.$ dry weight) of Chiridius armatus (A), Calanus hyperboreus (B), Metridia longa (C), and stage V copepodites (upper) and adult females (lower) of Euchaeta norvegica (D). Dry-weight (D.W., mg) values represent means for the individuals constituting the various samples. RNA concentrations calculated for individuals of standard-weight (see the text) and standardweight for each species shown as squares

$$
\mathrm{a}=\exp \cdot\left(\ln [\mathrm{RNA}]_{\mathrm{m}}+0.38 \ln \mathrm{W}_{\mathrm{m}}\right)
$$

where $(R N A)_{m}$ and $W_{m}$ are the measured average RNA concentration and dry weight, respectively, of a given species at a given time.

The seasonal trend in RNA concentration varied, but common for most species was an increase from late winter towards spring and summer (Figs. 2 to 4 ). A single seasonal maximum was found for the copepods Calanus hyperboreus, Metridia longa, and Euchaeta norvegica (Fig. 2 B-D) and for the polychaete Tomopteris helgolandica (Fig. 4 B). The 2 euphausiids Meganyctiphanes norvegica and Thysanoessa sp. had highest values in spring (Fig. 3 B, C). The copepod Chiridius armatus showed high values early in the year and in summer (Fig. 2 A), and the amphipod Parathemisto abyssorum exhibited inconsistent and large variation over the whole sampling period (Fig. 3 D). The other species usually showed a general trend of increasing RNA concentration when going from winter towards summer. Results for the species sam- pled only at 1 or 2 occasions are summarized in Table 1.

\section{DISCUSSION}

\section{Consideration of errors}

An initially rapid change in weight with a stabilization after a few days in the preservation medium is a general trend; Landahl and Nagell, 1978; Omori, 1978). The present results confirm this but also show that the amplitude in the changes is very different for crustacean species compared with more gelatinous species. However, there was no indication of a different stabilization period for gelatinous species, thus making it possible to use a simple conversion factor between preserved wet weight and dry weight for each species for preservation times longer than $2 \mathrm{~d}$.
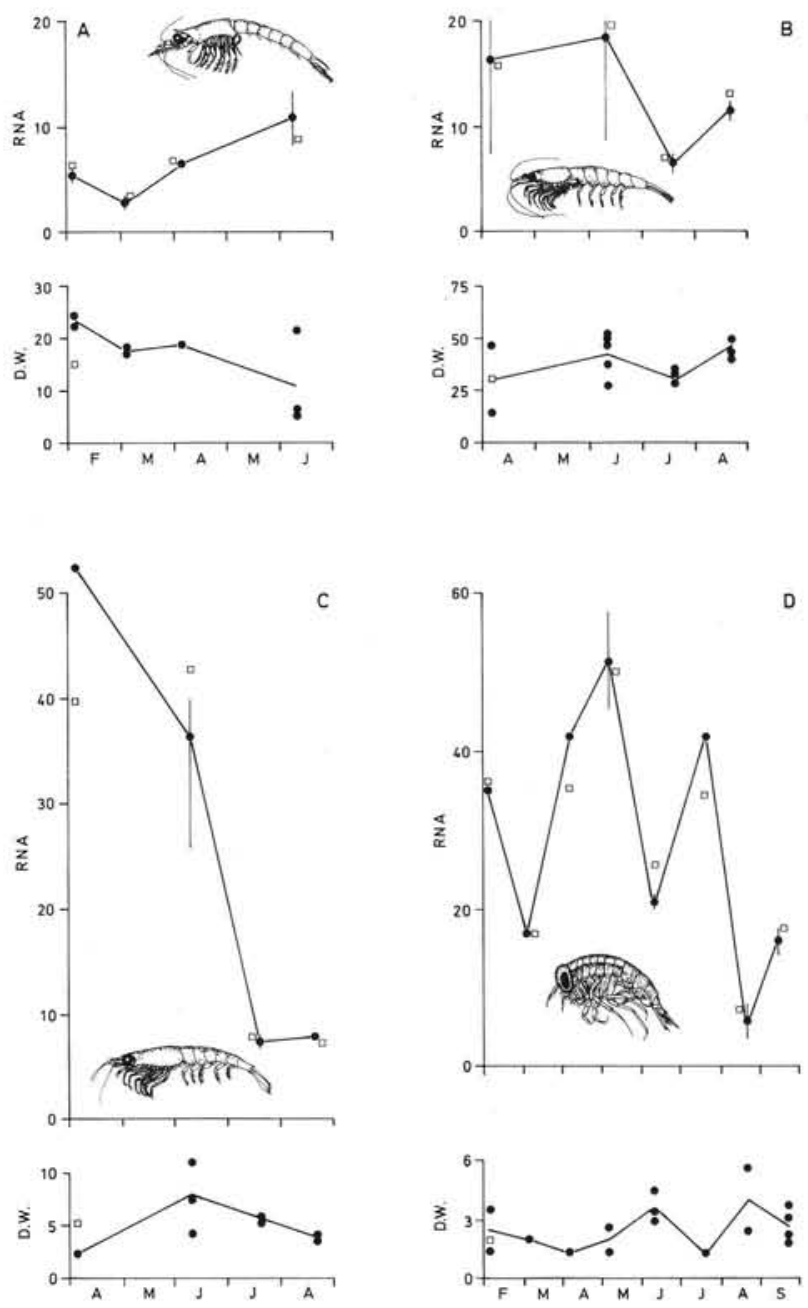

Fig. 3. Seasonal variation in RNA concentration of Boreomysis arctica (A), Meganyctiphanes norvegica (B), Thysanoessa sp. (C), and Parathemisto abyssorum (D). See legend to Fig. 2 for details 

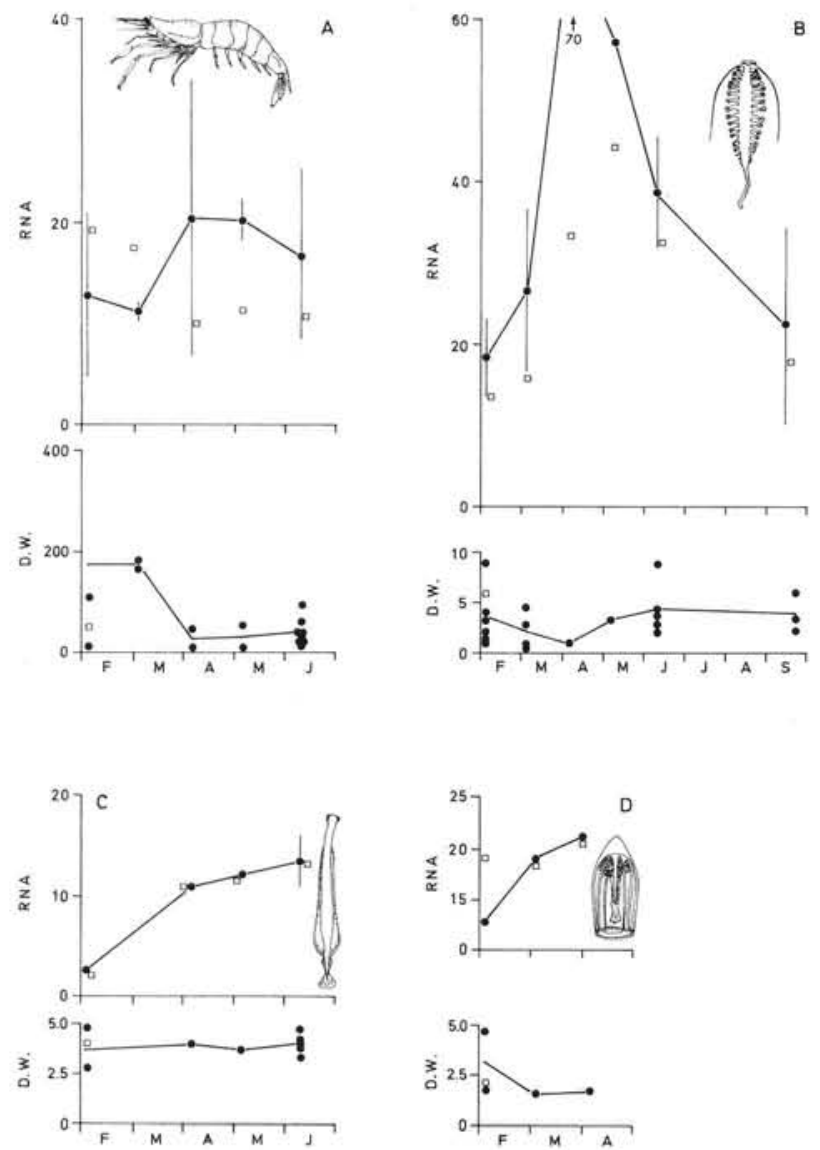

Fig. 4. Seasonal variation in RNA concentration of Pasiphaea multidentata (A), Tomopteris helgolandica (B), Eukrohnia hamata (C), and Aglantha digitale (D). See legend to Fig. 2 for details

The stability of RNA during prolonged storage in ethanol has been considered. Tests on the relationship between number of days preserved and the measured RNA concentrations revealed no significant correlation (t-test, $\mathrm{p}>0.05$ ) for any of the species. Inevitably the seasonal variation in RNA concentration interferes in

these tests but the findings of both high and low RNA concentrations in material preserved for long time further indicate independence between preservation time and measured RNA concentration. Thus, in the material sampled in April which was preserved for $54 \mathrm{~d}$ prior to analyses, high RNA concentrations were found for some species (Thysanoessa sp., Tomopteris helgolandica, Aglantha digitale) and low for others (Chiridius armatus, Metridia longa, Boreomysis arctica). The results shown in Figs. 2 to 4 therefore reflect real seasonal variation in RNA concentration of the species.

\section{Seasonal variation in RNA concentration and its implications}

Both field studies (Barnes et al., 1963; Båmstedt and Skjoldal, 1976; Skjoldal and Båmstedt, 1976; Pease, 1968) and controlled experiments (Bulow, 1970; Dagg and Littlepage, 1972; Haines, 1973; Buckley, 1979) have indicated a close correlation between feeding level, growth rate and RNA concentration. Haines (1980) also showed that the effect of changing primary production was transferred through several trophic levels to affect the RNA/DNA ratio of fish.

Theoretically, increasing feeding rate of an organism should induce increasing metabolic rate, since more energy is needed for handling, assimilation and biochemical processing of the food. Several studies have shown increasing metabolic rates of various boreal zooplankton species in spring (e.g. Marshall and Orr, 1958, 1966; Conover, 1959; Berner, 1962; Cowey and Corner, 1963; Haq, 1967; Conover and Corner, 1968; Butler et al., 1970; Mayzaud, 1973). Results from the macroplankton community in Kosterfjorden indicate maximum respiratory rates during spring and early summer for most species (Table 2).

Table 1. Individual dry weight (mg) and RNA concentration ( $\mu \mathrm{g} \mathrm{mg}^{-1}$ dry weight) of macrozooplankton species sampled in Kosterfjorden at 1 or 2 occasions between February and September 1976

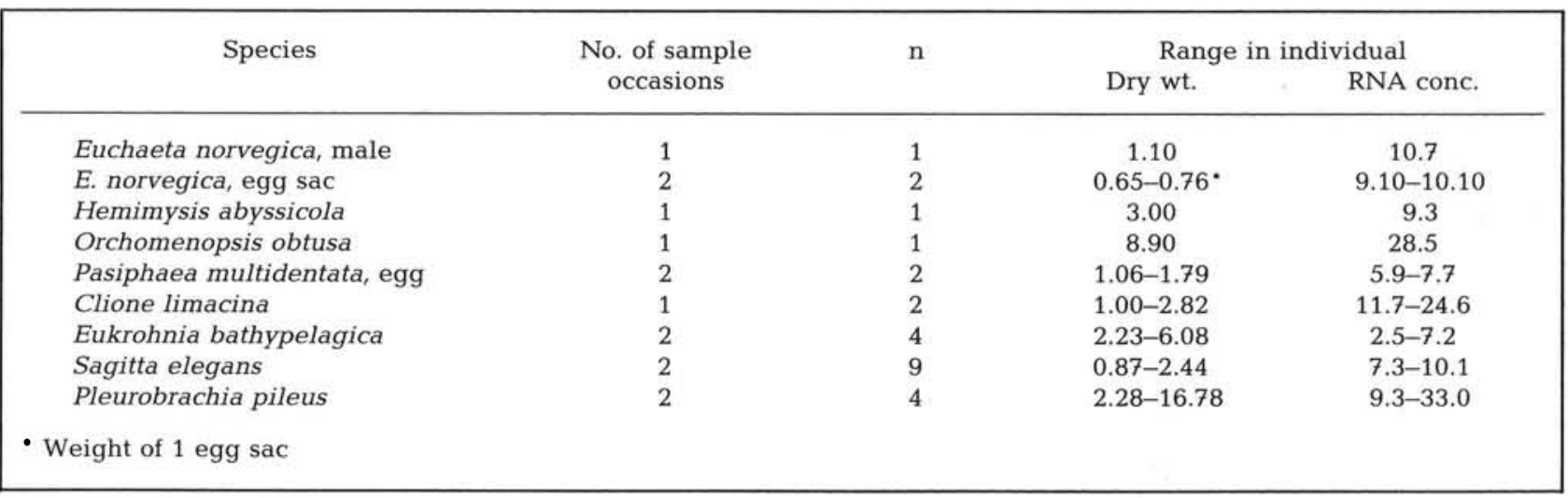


Table 2. Average respiration rate $\left(\mu \mathrm{l} \mathrm{O} \mathrm{mg}^{-1}\right.$ dry weight $\left.\mathrm{h}^{-1}\right)$ of macrozooplankton species sampled between February and September 1976 in Kosterfjorden

\begin{tabular}{|lcccccccc|}
\hline \multicolumn{1}{|c}{ Species } & Feb & Mar & Apr & May & Jun & Jul & Aug & Sep \\
\hline Calanus hyperboreus & - & 0.49 & 0.29 & 0.44 & 0.23 & - & 0.14 \\
Chiridius armatus & - & 0.79 & 0.68 & 0.76 & 0.52 & 0.44 & 0.56 & 0.56 \\
Euchaeta norvegica, c-V & - & 0.29 & 0.60 & 0.51 & 0.41 & 0.50 & - & 0.60 \\
E. norvegica, female & - & 0.36 & 0.44 & 0.55 & 0.35 & 0.37 & 0.35 & 0.46 \\
Metridia longa & - & 1.32 & 1.57 & 1.47 & 1.24 & 0.87 & 0.88 & 0.77 \\
Boreomysis arctica & 0.15 & 0.22 & 0.16 & 0.47 & 0.21 & - & 0.30 & 0.19 \\
Meganyctiphanes norvegica & - & 0.46 & 0.51 & 0.68 & 0.62 & 0.75 & 0.72 & 0.70 \\
Thysanoessa sp. & 0.41 & 0.84 & - & - & 1.00 & 0.66 & 0.60 & 0.88 \\
Parathemisto abyssorum & - & 0.58 & 0.58 & 0.88 & 0.39 & 0.62 & 0.41 & 0.46 \\
Pasiphaea multidentata & - & 0.31 & 0.61 & 0.71 & 0.51 & - & - & 0.79 \\
Eukrohnia hamata & 0.10 & 0.20 & 0.11 & 0.18 & - & - & - \\
Tomopteris helgolandica & 0.40 & 0.37 & 0.43 & 0.51 & 0.61 & - & 0.31 \\
Aglantha digitale & - & 0.42 & - & 0.19 & - & - & - \\
\end{tabular}

Since maturation inevitably must include synthesis of new body components to build up the gonads a correlation between RNA concentration and breeding cycle can a priori be postulated. A comparison between breeding occurrence and RNA concentration is therefore relevant.

In Korsfjorden, western Norway, situated at the same latitude as Kosterfjorden, Chiridius armatus has a halfyear life cycle, with main breeding periods in midwinter and mid-summer (Bakke and Alvarez-Valderhaug, 1978). The same breeding periodicity has been found for Euchaeta norvegica (Bakke, 1977). The 2 periods of high RNA concentration for the former species (Fig. 2 A) therefore coincide with periods of high breeding intensity. The single maximum in RNA concentration for female E. norvegica (Fig. 2 D) does not mean that the winter breeding was associated with low RNA concentration since no samples were taken between September and the beginning of February.

Calanus hyperboreus breeds early in the year (Matthews et al., 1978), thus at the same time as the RNA concentration is at its maximum (Fig. 2 B). Metridia longa from northern latitudes breeds in spring (Fosshagen, pers. comm.). The pronounced peak in RNA concentration in the beginning of June (Fig. 2 C) may reflect recruitment of 'young' adults, but since the breeding cycle may vary in time from year to year it is still possible that the peak in RNA concentration corresponds to a peak in maturity within the population.

Female Boreomysis arctica with developed brood pouch have been found from October to July in Kosterfjorden (Båmstedt, unpubl.). This indicates almost continuous reproduction and the variation in RNA concentration (Fig. $3 \mathrm{~A}$ ) does not conflict with this.

Meganyctiphanes norvegica, Thysanoessa inermis and $T$. raschii which commonly occur in Kosterfjorden have their main breeding period from early spring to early summer (Mauchlin and Fisher, 1969; Matthews, 1973; Jörgensen and Matthews, 1975), during this period high RNA concentration was found (Fig. $3 \mathrm{~B}, \mathrm{C}$ ).

Studies at the Norwegian west coast show that Pasiphaea multidentata breeds the year around, but most intensely in early summer and early autumn (Matthews and Pinnoi, 1973). Growth of gonads prior to breeding may be one reason why the weight-corrected RNA concentration was high in February-March (Fig. 4 A).

Female Parathemisto abyssorum carrying eggs or embryos occur throughout the year in Kosterfjorden (Båmstedt, unpubl.). The fluctuating RNA concentration found (Fig. 3 D) may therefore reflect natural variability in maturity of sampled animals.

The frequency of ripe Tomopteris helgolandica increases dramatically during spring in Kosterfjorden and in early summer up to $60 \%$ of the individuals in the population is made up of egg-bearing females (Båmstedt, unpubl.). The pronounced peak in RNA concentration (Fig. 4 B) therefore correlates well with the breeding cycle.

Eukrohnia hamata from northern latitudes breeds most intensely in spring and autumn but with breeding occurring with low intensity throughout the summer (Sands, 1980). Aglantha digitale from boreal waters breeds in spring (Matthews, pers. commn.). Increasing RNA concentration in early spring for these 2 species (Fig. 4 C, D) may thus indicate a coupling with the breeding cycles.

It is evident therefore that there is a general correlation between metabolic rate, breeding cycle and RNA concentration of the species investigated. What are then the causal relationships between these factors? RNA is not involved in the catabolic processes of metabolism and any close correlation between total metabolic rate and RNA concentration is therefore not 
expected. However, RNA is involved in the production of proteins which are incorporated in new tissue. Since increasing feeding activity theoretically involves higher metabolic rate (see above) and gives the base for a higher growth rate (synthesis of proteins) the correlation between metabolic rate and RNA concentration is probably only a reflection of the fact that both are governed by the feeding level. The gonad maturation must also include some synthesis of proteins. The material used for this may be taken from the food or from stored sources. The fact that many species breed in spring when food is abundant indicates that feeding may be important for the final maturation. Winter breeders (e.g. Chiridius armatus and Euchaeta norvegica) must rely more on stored energy. In both cases it is logical to suggest that the maturation processes with its synthesis of proteins require concomittant increase in RNA concentration and that the necessary condition for this is good food availability or high level of stored energy. More precise information on the causal relationships between RNA concentration and feeding, growth and reproduction require further investigations.

Acknowledgements. I am thankful to O. Vahl and H. R. Skjoldal for their comments on the manuscript. This study was financially supported by the Swedish Natural Science Research Council.

\section{LITERATURE CITED}

Bakke, J. L. W. (1977). Ecological studies on the deep-water pelagic community of Korsfjorden, western Norway. Population dynamics of Euchaeta norvegica (Crustacea, Copepoda) from 1971 to 1974. Sarsia 63: 49-55

Bakke, J. L. W., Alvarez Valderhaug, V. (1978). Ecological studies on the deep-water pelagic community of Korsfjorden, western Norway. Population biology, biomass, and calorie content of Chiridius armatus (Crustacea, Copepoda). Sarsia 63: 247-254

Båmstedt, U., Skjoldal, H. R. (1976). Studies on the deepwater pelagic community of Korsfjorden, western Norway. Adenosine phosphates and nucleic acids in Euchaeta norvegica (Copepoda) in relation to its life cycle. Sarsia 60: 63-80

Båmstedt, U., Skjoldal, H. R. (1980). RNA concentration of zooplankton: Relationship with size and growth. Limnol. Oceanogr. 25: 304-316

Barnes, H., Barnes, M., Finlayson, D. M. (1963). The seasonal change in body weight, biochemical composition, and oxygen uptake of two common boreoarctic cirripedes, Balanus balanoides and B. balanus. J. mar. biol. Ass. U. K. 43: $185-211$

Baudouin, M.-F., Scoppa, P. (1975). The determination of nucleic acids in freshwater plankton and its ecological implications. Freshwater Biol. 5: 115-120

Berner, $\AA$. (1962). Feeding and respiration in the copepod Temora longicornis (Müller). J. mar. biol. Ass. U. K. 42: $625-640$
Buckley, L. J. (1979). Relationships between RNA-DNA ratio, prey density, and growth rate in Atlantic cod (Gadus morhua) larvae. J. Fish. Res. Bd Can. 36: 1497-1502

Bulow, F. J. (1970). RNA-DNA ratios as indicators of recent growth rates of fish. J. Fish. Res. Bd Can. 27: 2343-2349

Butler, E. I., Corner, E. D. S., Marshall, S. M. (1970). On the nutrition and metabolism of zooplankton. VII. Seasonal survey of nitrogen and phosphorus excretion by Calanus in the Clyde Sea-area. J. mar. biol. Ass. U. K. 50: 525-560

Conover, R. J. (1959). Regional and seasonal variation in the respiratory rate of marine copepods. Limnol. Oceanogr. 4: 259-268

Conover, R. J., Corner, E. D. S. (1968). Respiration and nitrogen excretion by some marine zooplankton in relation to their life cycles. J. mar. biol. Ass. U. K. 48: 49-75

Cowey, C. B., Corner, E. D. S. (1963). On the nutrition and metabolism of zooplankton. II. The relationship between the marine copepod Calanus helgolandicus and particulate material in Plymouth sea water, in terms of amino acid composition. J. mar. biol. Ass. U. K. 43: 495-511

Dagg, M. J., Littlepage, J. L. (1972). Relationships between growth rate and RNA, DNA, protein and dry weight in Artemia salina and Euchaeta elongata. Mar. Biol. 17: $162-170$

Haines, T. A. (1973). An evaluation of RNA-DNA ratio as a measure of long-term growth in fish populations. J. Fish. Res. Bd Can. 30: 195-199

Haines, T. A. (1980). Seasonal pattern of muscle RNA-DNA ratio and growth in black crappie, Pomoxis nigromaculatus. Env. Biol. Fish. 5: 67-70

Haq, S. M. (1967). Nutritional physiology of Metridia lucens and $M$. longa from the Gulf of Maine. Limnol. Oceanogr. 12: $40-51$

Jörgensen, G., Matthews, J. B. L. (1975). Ecological studies on the deep-water pelagic community of Korsfjorden, western Norway. Population dynamics of six species of euphausiids in 1968 and 1969. Sarsia 59: 67-84

Kearns, P. K., Atchison, G. J. (1979). Effects of trace metals on growth of yellow perch (Perca flavescens) as measured by RNA-DNA ratios. Env. Biol. Fish. 4: 383-387

Landahl, C.-C., Nagell, B. (1978). Influence of the season and of preservation methods on wet and dry weights of larvae of Chironomus plumosus L. Int. Revue ges. Hydrobiol. 63: 405-410

Leick, V. (1967). Growth rate dependency of protein and nucleic acid composition in Tetrahymena pyriformis and the control of synthesis of ribosomal and transfer RNA. C. r. Trav. Lab. Carlsberg 36: 113-126

Marshall, S. M., Orr, A. P. (1958). On the biology of Calanus finmarchicus. X. Seasonal changes in oxygen consumption. J. mar. biol. Ass. U. K. 37: 459-472

Marshall, S. M., Orr, A. P. (1966). Respiration and feeding in some small copepods. J. mar. biol. Ass. U. K. 46: 513-530

Matthews, J. B. L. (1973). Ecological studies on the deepwater pelagic community of Korsfjorden, western Norway. Population dynamics of Meganyctiphanes norvegica (Crustacea, Euphausiacea) in 1968 and 1969. Sarsia 54: 75-90

Matthews, J. B. L., Hestad, L., Bakke, J. L. W. (1978). Ecological studies in Korsfjorden, western Norway. The generations and stocks of Calanus hyperboreus and C. finmarchicus in 1971-1974. Oceanol. Acta 1: 277-284

Mauchline, J., Fisher, L. R. (1969). The biology of euphausiids. Adv, mar. Biol. 7: 1-454

Mayzaud, P. (1973). Respiration and nitrogen excretion of zooplankton. II. Studies of the metbolic characteristics of starved animals. Mar. Biol. 21: 19-28 
Munro, H. N., Fleck, A. (1966). Recent developments in the measurements of nucleic acids in biological materials. A supplementary review. Analyst, Lond. 91: 78-88

Munro, H. N., Gray, J. A. M. (1969). The nucleic acid content of sceletal muscle and liver in mammals of different body size. Comp. Biochem. Physiol. 28: 897-905

Neidhardt, F. C., Magasanic, B. (1960). Studies on the role of ribonucleic acid in the growth of bacteria. Biochem. Biophys. Acta 42: 99-116

Omori, M. (1978). Some factors affecting on dry weight, organic weight and concentrations of carbon and nitrogen in freshly prepared and in preserved zooplankton. Int. Revue ges. Hydrobiol. 63: 261-269

Pease, A. K. (1968). The use of the estimates of ribonucleic acid to predict growth rates of zooplankton organisms. M. Sc. thesis, University of British Columbia

Sands, N. J. (1980). Ecological studies on the deep-water pelagic community of Korsfjorden, western Norway. Population dynamics of the chaetognaths from 1971-1974. Sarsia 65: 1-12
Schmidt, G., Thannhauser, S. J. (1945). A method for the determination of desoxyribonucleic acid, ribonucleic acid, and phosphoproteins in animal tissues. J. Biol. Chem. 161: 83-89

Schneider, W. C. (1957). Determination of nucleic acids in tissues by pentose analysis. In: Calwich, S. P., Kaplan, N. O. (eds.) Methods in enzymology. III. Academic Press, New York, p. 680-684

Skjoldal, H. R., Båmstedt, U. (1976). Studies on the deepwater pelagic community of Korsfjorden, western Norway. Adenosine phosphates and nucleic acids in Meganyctiphanes norvegica (Euphausiacea) in relation to its life cycle. Sarsia 61: 1-14

Sutcliffe, W. H., Jr. (1965). Growth estimates from ribonucleic acid content in some small organisms. Limnol. Oceanogr. 10 (Suppl.): R253-R258

Sutcliffe, W. H., Jr. (1970). Relationship between growth rate and ribonucleic acid concentration in some invertebrates. J. Fish. Res. Bd Can. 27: 606-609

This paper was presented by Dr. H. R. Skjoldal; it was accepted for printing on December 2, 1982 